\title{
UMD-DYSF, A Novel Locus Specific Database for the Compilation and Interactive Analysis of Mutations in the Dysferlin Gene
}

Gaelle Blandin ${ }^{1,2}$, Christophe Beroud ${ }^{3}$, Veronique Labelle4, Karine Nguyen ${ }^{4}$, Nicolas Wein ${ }^{1,2}$, Dalil Hamroun ${ }^{3}$, Brad Williams 5 , Nilah Monnier ${ }^{5}$, Laura E. Rufibach ${ }^{5}$, Jon Andoni Urtizberea ${ }^{6}$, Pierre Cau ${ }^{1,2,4}$, Marc Bartoli ${ }^{1,2}$, Nicolas Lévy ${ }^{1,2,4}$, and Martin Krahn ${ }^{1,2,4 *}$.

1 Aix-Marseille Univ, UMR 910, Faculté de Médecine Timone, 13385, Marseille, France; 2 Inserm, UMR 910, 13385, Marseille, France; 3 Université Montpellier 1, CHU de Montpellier and Inserm U827, 34000, Montpellier, France; 4 APHM, Hôpital d'Enfants de la Timone, Département de Génétique Médicale et de Biologie Cellulaire, 13385, Marseille, France; 5 Jain Foundation, Bellevue, WA, 98005, USA; 6 APHP, Hôpital Marin, 64700, Hendaye, France

\begin{abstract}
Mutations in the dysferlin gene ( $D Y S F)$ lead t o a com plete or partial abs ence of the dysferlin protein in skeletal muscles and are at the orig in of dysferlinopathies, a heterogeneous group of rare au tosomal rece ssive i nherited n euromuscular disorders. As a step to wards a b etter understanding of the DYSF m utational sp ectrum, a nd to wards p ossible in clusion of patients in future therapeutic clinical trials, we set up the Universal Mutation Database for Dysferlin (UMDDYSF), a L ocus-Specific Dat abase dev eloped with the UMD® s oftware. The main objective of UMD-DYSF is to provide an updated compilation of mutational data and relevant interactive tools for the a nalysis of $D Y S F$ s equence variants, for diagn ostic and res earch p urposes. In particular, specific a lgorithms ca $n$ facilitate $t$ he i nterpretation of newly identified i ntronic, missense- o $r$ isosemantic-exonic sequence variants, a problem encountered recurrently during genetic diagnosis in dysferlinopathies. UMD -DYSF v 1.0 is freely acce ssible at www.umd.be/DYSF/. It con tains a total of 742 mutational entries corresponding to 266 different disease-causing mutations identified in 558 patients worldwide diagnosed with dysferlinopathy. This article presents for the first time a comprehensive analysis of the dysferlin mutational spectrum based on all compiled DYSF diseasecausing mutations reported in the literature to date, and using the main bioinformatics tools offered in UMD-DYSF. C2011 Wiley-Liss, Inc.
\end{abstract}

KEY WORDS: LSDB, UMD, dysferlin, DYSF, LGMD, muscle 


\section{INTRODUCTION}

In 1998, the groups of Robert H. Brown Jr. (Liu, et al., 1998) and Kate Bushby (Bashir, et al., 1998) identified the genetic ca use of the a utosomal recess ive muscle-wasting di seases Miyoshi myopathy (MIM\# 254130), and Limb Girdle Muscular Dystrophy type 2B (LGMD2B; MIM\# 253601) as resulting from mutations in a novel gene on ch romosome 2p13. T he en coded prot ein was named dy sferlin ( DYSF; MIM\# 6030 09), rel ating t o i ts involvement in muscular d ystrophy, an $\mathrm{d}$ homology with the C. el egans fer-1 prot ein. Using membrane repai $\mathrm{r}$ assays o $\mathrm{n}$ muscle $\mathrm{f}$ ibers from $\mathrm{d}$ ysferlin-deficient mouse models, th e $\mathrm{g}$ roups of $\mathrm{P}$ aul $\mathrm{McNeil} / \mathrm{Ke}$ vin Campbell (Bansal, et al., 20 03) and Robert H. B rown Jr. (Lennon, et al., 2003) subsequently demonstrated a central role for dysferlin in sarcolemmal repair after membrane injury. This established Miyoshi myopathy and LGMD2B as the first entities of a new subgroup of muscular dystrophies, due to defective membrane-repair.

From a clinical point of view, numerous reports corroborated the implication of mutated dysferlin in muscular dystrophy, and in particular in a high proportion of LGMD. In the past ten years, regular mutational analysis has allowed for better ch aracterization of the phenotypic manifestations associated with deleterious mutations in the $D Y S F$ gene. The main clinical presentations are the distal-onset muscular dystrophy called, Miyoshi myopathy and the proximal-onset form LGMD2B, both characterized by progressive muscle weakness, usually appearing in the second decade, an d highly elevated serum creatine kinase (CK) levels. Progressively, the description of different phenotypes caused by DYSF mutations (Illa, et al., 2001; Klinge, et al., 2008; Nguyen, et al., 2005; Nguyen, et al., 2007; Okahashi, et al., 2008; Paradas, et al., 2009; Seror, et al., 2008; Spuler, et al., 2008; Ueyama, et al., 2002; Wenzel, et al., 2007), in addition to the "typical" LGMD and Miyoshi phenotypes, unraveled a wide spectrum of phenotypes, ranging from clinically asymptomatic, isolated hyperCKemia to severe and early onset presentations (Bushby, 2000; Laval and Bu shby, 2004; Urtizberea, et al., 2008). This wide ran ge of clinical pres entations is collectively referred to as dysferlinopathies.

$D Y S F$ was initially shown to be expressed in the skeletal and cardiac muscle tissues (Bashir, et al., 1998; Liu, et al., 1998), in monocytes (Ho, et al., 2002), as well as in a variety of tissues, including liver, lung, kidney, pancreas, brain, and placenta (Bashir, et al., 1998; Liu, et al., 1998). More recent studies have isolated 14 is oforms that are differentially ex pressed a mong ti ssues. T hese is oforms orig inate $\mathrm{f}$ rom $\mathrm{t}$ he diff erential $\mathrm{u}$ se of prom oters an $\mathrm{d}$ alternative exons which have been identified, respectively DYSF (AF075575) (Foxton, et al., 2004) and DYSF_v1 (Pramono, et al., 2006) promoters, and al ternative exons $5 \mathrm{a}$ and 40a (Pramono, et al., 2009). Is oform 8, which contains the 55 ca nonical exons transcribed via the DYSF promoter, constitutes the major DYSF transcript $(73 \%)$ among all report ed isoforms expressed in skeletal muscle, but is not ex pressed in monocytes where isoform 13 (NM_001130980; containing exon 5a) represents the main dysferlin messenger (44\%) (Pramono, et al., 2009). The other isoforms are le ss expressed in skeletal muscle and blood. In addition to the canonical messenger composed of 55 exons, splice variants lacking exon 17 are expressed at early stages of myogenic cell differentiation and also constitute predominant dysferlin tran scripts in mature peripheral nerve tis sue (Salani, et al., 20 04). To date, th e functional role of the different messengers remains unknown.

Due to th e larg e size of the DYSF g ene, which s pans a gen omic locus of approx imately $233 \mathrm{k} \mathrm{bp}$, mutation screening is c hallenging on a ro utine cli nical basis. Mutational an alysis of DYSF is further co mplicated by the large mutational s pectrum (det ailed in this art icle), an d a h igh proport ion of "private" mutations, which leaves molecular geneticists with the recu rrent d ifficulty of i nterpreting novel DYSF s equence v ariants, in particular putative splicing and missense variants.

Until now, the Leiden Open (source) Variation Database established in 1998 for dysferlin (LOVD Dysferlin), has been $t$ he un ique Locus Specif ic Databas e s erving as a pu blic repos itory for hum an $d$ ysferlin v ariants (www.lovd.nl/DYSF). O ur 1 aboratory, as many ot hers, widely us es this valuable res ource. O n N ovember, 18, 2011, L OVD D ysferlin cons isted of $424 \mathrm{u}$ nique sequence $\mathrm{v}$ ariants, including published or directly s ubmitted (unpublished) $\mathrm{v}$ ariants, $\mathrm{b}$ eing eith er $\mathrm{d}$ isease-causing mutations ( $c a .300 \mathrm{v}$ ariants) or $\mathrm{p}$ olymorphisms ( $c a .100$ variants). While LOVD i s a efficient and convenient to ol for gene-centered collection, curation and display of DNA $v$ ariation, $d$ ata an alysis o ptions are li mited. T he Un iversal M utation Datab ase ( UMD ${ }^{\circledR}$ ) L ocus Specific Databases (Beroud, et al., 2000; Beroud, et al., 2005) have been developed specifically to allow for the collection of mutational $d$ ata an $d p$ rovide $n$ umerous $b$ ioinformatics tools $f$ or th $e$ in teractive an alysis o $f$ mutational $d$ ata, including the a nalysis of novel sequence variants. $E$ ven more, the $\mathrm{UM}{ }^{\circledR}$ software is $\mathrm{v}$ ery $\mathrm{f}$ lexible $f$ or the development of novel tools, based on questions arising in the research field.

In the present article, we describe the online version of UMD-DYSF, freely accessible at www.umd.be/DYSF/. In co mplement to LOVD D ysferlin, UMD -DYSF n ot o nly ref erences all $\mathrm{p}$ reviously $\mathrm{p}$ ublished $\mathrm{d}$ isease-causing 
mutations identified in the DYSF gene but also includes interactive bioinformatics tools for the analysis of DYSF sequence variants. I $n$ particular, UMD- DYSF o ffers a c omputational procedu re $f$ or the an alysis o $f$ pos sible deleterious mutations a ffecting sp licing signals in the dysferlin g ene, u sing the Hu man Sp licing Fi nder (HSF) algorithm (D esmet, et al ., 2009) an d i ntegrates the U MD-Predictor t ool for the an alysis of missense variants (Frederic, et al., 2009). Furthermore, interactive functions allow for analysis of the full UMD-DYSF dataset, single mutational e vents or c ustomized subsets of mutations re ferenced in the database. We previously used an offline version of UMD-DYSF to successfully analyse the mutational spectrum of a large cohort of patients analysed for $D Y S F$ mutations in our diagnostic laboratory (Krahn, et al., 2009a). To further illustrate the use of UMD-DYSF, we here report the results of statistical analyses of the $D Y S F$ mutational spectrum based for the first ti me on all compiled DYSF disease-causing mutations reported in the literature to date.

\section{THE UMD-DYSF DATABASE}

\section{Database description}

The UMD- DYSF databas e was dev eloped u sing a s oftware pack age of specific rou tines, which allo ws optimized multicriteria s earch and s orting of dat a (Beroud, et al., 2000; Berou d, et al., 2005). Mu tational dat a entries are standardized to $\mathrm{f}$ acilitate mutational an alysis, a s prev iously described (Collod-Beroud, et al., 2003; Frederic, et al., 2008). Each entry corresponds to one mutation associated with one affected individual, either index patient or affected relative. At the moment, UMD-DYSF includes DYSF mutations described or pre dicted in the literature as d eleterious, exclusively. However, in future versions, UMD-DYSF will include unpublished data for disease-causing variants (see the DATABASE UPDATE section). UMD-DYSF is currently not aimed at collecting polymorphism dat a from pat ients beca use $\mathrm{c}$ urrent di agnostic s creening methods are not homogenized bet ween laboratories, an $\mathrm{d}$ res ults of polymorphism pat ient dat a are $\mathrm{t}$ herefore bi ased. $\mathrm{F}$ or users i nterested i $\mathrm{n}$ kn own polymorphism data, the UMD-DYSF website links to the UCSC genome browser page for DYSF (Dreszer, et al., 2011) (http://genome.ucsc.edu) an d each UMD-DYSF mutation d escription $p$ age li nks to the co llection of sequence variations available in LOVD Dysferlin for the corresponding nucleotide position. As d ysferlinopathies are an au tosomal reces sive dis ease, u sers s hould be w arned th at "polymorphism data" is sued from lar ge-scale "normal" co ntrol st udies can b e "contaminated" with tr uly $\mathrm{p}$ athogenic DYSF s equence v ariants found at a heterozygous state in healthy carriers. These variants should thus be confronted to pathogenicity prediction tools -such as those available in UMD-DYSF- to further evaluate the possibility of a deleterious effect.

The following mutational e vents can be en tered into the $\mathrm{d}$ atabase: point mutations, insertions, deletions, and insertions-deletions (i ntronic an d/or ex onic); a s well a $\mathrm{s}$ mono- o $\mathrm{r}$ multi-exonic 1 arge-sized d eletions o $\mathrm{r}$ duplications. Several levels of information are provided for each mutation, including the affected exon and codon number, wild-type and mutant codon sequence, type of mutational event, mutation nomenclature, wild-type and mutant a mino-acid, a ffected do main, etc. W henever ava ilable, we als o included i $\mathrm{n}$ he databas e c linical information; however, in most publications, only the main phenotype data (i.e. LGMD2B or Mi yoshi myopathy), but no detailed information, are described.

Mutational events are automatically described using the official nomenclature of the Human Genome Variation Society (den D unnen and A ntonarakis, 2000), an d relating to the human DYSF cDN A s equence of re ference (isoform 8, G enBank \#N M_003494.2) w hich corres ponds t o t he major DYSF tran script am ong all rep orted isoforms expressed in skeletal muscle (Pramono, et al., 2009). DYSF isoform 8 (6243bp) is transcribed under the $D Y S F$ promoter and contains the 55 canonical exons, with exons $5 \mathrm{a}$ and $40 \mathrm{a}$ exclusion and exon 17 inclusion. The dysferlin protein sequence was annotated for $\mathrm{C} 2$ domains, ferl in family domains, DysF domains and TM domain based on predictions from Pfam 25.0 (F inn, et al., 2010) and S MART 6 (L etunic, et al., 2009) and for highly conserved res idues ex pected to be involved in ca lcium coordination as $\mathrm{d}$ escribed by Therrien an $\mathrm{d}$ co lleagues (Therrien, et al., 200 6). Us ers of UMD-DYSF ca n verify whether ex onic mutations a ffect ann otated structural domains or highly conserved residues.

Interactive a nalysis of DYSF mutational dat a included in the dat abase was don e us ing previously des cribed sorting- and research-functions (Beroud, et al., 2000; Beroud, et al., 2 005). In addition, the present version of the UMD-package includes novel routines to a ssist the design of new therapeutic tools. Analysis tools and functions accessible on the UMD-DYSF website are des cribed in T able 1, and a brief user guide can be do wnloaded from the website. 
Table 1. Complete list of tools and functions available on the UMD-DYSF website (www.umd.be/DYSF/)

\begin{tabular}{|c|c|}
\hline Function or tool name & Function or tool description \\
\hline I found a mutation & $\begin{array}{l}\text { Displays a table of the various mutational events registered in UMD-DYSF } \\
\text { for a given position. }\end{array}$ \\
\hline $\begin{array}{l}\text { I want to analyze the impact of } \\
\text { a missense variant }\end{array}$ & $\begin{array}{l}\text { Uses the UMD-Predictor }{ }^{\circledR} \text { algorithm to predict the pathogenicity of all } \\
\text { possible non-synonymous or synonymous mutations from the } D Y S F \text { gene. }\end{array}$ \\
\hline $\begin{array}{l}\text { I want to analyze an intronic } \\
\text { variant }\end{array}$ & $\begin{array}{l}\text { Uses the Human Splicing Finder tool to evaluate the consequences of } \\
\text { substitutions on splicing. }\end{array}$ \\
\hline I want to search the database & $\begin{array}{l}\text { Allows the selection of a specific subset of the database. Results are } \\
\text { displayed as a list on the screen. }\end{array}$ \\
\hline $\begin{array}{l}\text { Predicted impact of all } \\
\text { previously reported missense } \\
\text { variations }\end{array}$ & $\begin{array}{l}\text { Uses the UMD-Predictor }{ }^{\circledR} \text { tool to predict the pathogenicity of all UMD- } \\
\text { DYSF missense variants localized in the coding sequence. }\end{array}$ \\
\hline Global analysis & Gives a summary of mutation types. \\
\hline Position & $\begin{array}{l}\text { Studies the distribution of mutations at the nucleotide level to identify } \\
\text { preferential mutation sites. }\end{array}$ \\
\hline Potential stop codons & $\begin{array}{l}\text { Displays all codons from a specific exon that can be mutated into a stop } \\
\text { codon by a single substitution. }\end{array}$ \\
\hline Mutation map & $\begin{array}{l}\text { Displays the distribution of the various mutations along the gene and the } \\
\text { protein. }\end{array}$ \\
\hline Deletion map & $\begin{array}{l}\text { Displays the distribution of the various deletions along the gene and the } \\
\text { protein. }\end{array}$ \\
\hline Stop codon map & $\begin{array}{l}\text { Displays the exon phasing and the position and number of reported nonsense } \\
\text { mutations. }\end{array}$ \\
\hline Geographic distribution & Displays geographic origin of patients. \\
\hline Binary comparison & $\begin{array}{l}\text { Displays the distribution of the various mutations along the gene for two } \\
\text { chosen subsets of the database. }\end{array}$ \\
\hline Stat exons & $\begin{array}{l}\text { Studies the distribution of mutations in the different exons. It enables } \\
\text { detection of a statistically significant difference between observed and } \\
\text { expected mutations }\end{array}$ \\
\hline Distribution by exon & Displays the partition of each type of mutation in each exon \\
\hline Structure & $\begin{array}{l}\text { Studies the distribution of allelic mutations both in the various structural } \\
\text { domains of the protein and in the highly conserved residues expected to be } \\
\text { implicated in calcium coordination }\end{array}$ \\
\hline
\end{tabular}

\section{Database entries}

The UMD-DYSF v 1.0 (April 12, 2011 ) contains a total of 742 en tries corresponding to mutational data from 558 patients diagnosed with primary dysferlinopathy and previously reported in the lite rature as dis ease-causing mutations. The total number of patients a mounts to 401 i ndex cases (557 mutational entries) and 157 rel atives. Among all UMD-DYSF entries, 192 entries from 129 patients correspond to mutations identified in our laboratory (Khadilkar, et al., 2008; K rahn, et al., 2009a; K rahn, et al., 2009b; K rahn, et a 1., 2010; N guyen, et al., 2005; Nguyen, et al., 2007; Seror, et al., 2008) w hile the others correspond to mutational data reported in 55 additional publications ( see www.umd.be/DYSF/ for a co mprehensive li st o f re ferences). All mutational d ata can $b$ e visualized through the "Search" function described in Table 1 and downloaded from the UMD-DYSF website.

\section{Bioinformatics tools for the interpretation of sequence variants}

A recurrent problem in genetic diagnosis is the interpretation of sequence variants, including the difficulty in predicting the impact of a genomic variation on the pre-mRNA maturation and the mRNA translation mechanisms, and in predicting any deleterious effect on the mRNA and protein stability. The Human Gene Mutation Database (professional rel ease 2010.4) which col lects al 1 known gene l esions res ponsible for hum an i nherited di seases 
(Stenson, et al., 2009), reports a total of 108046 mutational entries, 54\% of which are missense mutations, as well as mutations affecting RNA splicing. Interpretation of the effect of DYSF missense variants and identification of $D Y S F$ splice variants is facilitated by a number of bioinformatics tools integrated into UMD-DYSF and available online.

The HSF tool is based on UMD al gorithms and predicts consequences of mutations affecting existing splice signals (don or an d acceptor sites, bran chpoints a nd cis-acting ele ments s uch a s ex onic s plicing enh ancers and silencers) or possibly creating novel ectopic splicing sequences. These algorithms are integrated into UMD-DYSF to allow for the a nalysis of sequence v ariants. Detailed a nalysis of UMD -DYSF ab normal splicing variants is described below.

To further dis criminate bet ween neutral and path ogenic sequence variations, UMD-DYSF also integ rates the recently developed UMD-Predictor tool (Frederic, et al., 2009). UMD-Predictor combines data such as localization within the protein, conservation and biochemical properties of the mutant and wild-type residues, as well as results from HSF analysis to calc ulate a path ogenicity score ranging from 0 to $100 \mathrm{f}$ or each missense variant (score $>65$ indicates a $\mathrm{p}$ robable or highly likely $\mathrm{p}$ athogenicity). Its e fficiency for predicting $\mathrm{p}$ athogenic missense mutations was demonstrated by a se nsitivity of $95.4 \%$ and a p ositive predictive value of $99.5 \%$ (Frederic, et al., 2009 ). The UMD-Predictor s core was co mputed for all UMD -DYSF missense variant e ntries and can be con sulted on the UMD-DYSF website using the "Predicted Im pact of al 1 Previously Rep orted Mis sense Variatio ns" fu nction. Although all variants predicted or described in the literature to be deleterious were entered into UMD-DYSF, 5\% were predi cted as probabl e or 1 ikely pol ymorphisms us ing UMD-Predictor ( pathogenicity s core $<65$ ). These variants could correspond to true polymorphisms in patients for whom the accurate deleterious mutation has been missed du ring g enetic testing (i ncomplete mutation det ection rates of pre-screening tec hniques $\mathrm{s}$ uch as Sing le Strand Conformation Polymorphism analysis or Denaturing High Pressure Liquid Chromatography; mutations not detected $\mathrm{u}$ sing rou tine s equencing approach es such as large g enomic rearran gements an $\mathrm{d}$ "deep" $\mathrm{i}$ ntronic mutations; etc.). Mo re likely, these variants spot cases for which the UMD-Predictor algorithm lacked predictive elements to accu rately i nterpret the path ogenic e ffect of the s equence $v$ ariant. More gen erally, for $v$ ariants of unclear $\mathrm{p}$ athogenicity, $\mathrm{d}$ efinitive co nclusion o $\mathrm{n}$ their $\mathrm{p}$ ossible $\mathrm{d}$ eleterious eff ect will o nly $\mathrm{b}$ e ach ievable with integration of novel functional data in to the UMD-Predictor alg orithm. In particular, b ioinformatics p redictions can greatly benefit from sequencing data of mutated DYSF RNAs and proteins, and from novel functional elements that would shed light on molecular roles and functions of dysferlin, domain organisation and critical residues of the protein.

\section{Bioinformatics routines to assist the design of therapeutic strategies}

Two i nteresting tools av ailable on the U MD-DYSF website ( Table 1) h ave been des igned to h elp dev elop certain types of therapeutic a pproaches for dysferlinopathies. In partic ular, several nonsense mutations could be targets for pos sible therapeutic approaches bas ed on a minoglycoside read through of stop codons (Wang, et al., 2010). The "Potential Stop Codon" function gives the list of codons that can lead to a premature termination codon (PTC) when mutated by a single substitution; along with the number of such mutations reported in UMD-DYSF. This function also provides statistical calc ulation ab out the environment of observed PTC compared to potential PTC for which no mutation has ever been reported. The distribution of nonsense mutations reported in the DYSF gene is des cribed below. In addition, the "Stop Codon Map" function is a UMD newly i mplemented tool $t$ hat displays the exon phasing and the position and number of reported nonsense mutations. This function has been designed to facilitate envisaging exon skipping strategies (Aartsma-Rus, et al., 2010; Levy, et al., 2010; W ein, et al., 2010).

\section{Analysis of the DYSF mutational spectrum}

\section{General statistics}

Mutational data from large c ohorts of patients rep eatedly revealed a larg e mutational spectrum for the DYSF gene, with a high proportion of missense changes, or frameshifting insertions and/or deletions (for example, (Aoki, et al., 2001; Cagliani, et al., 2003; De Luna, et al., 2007; Guglieri, et al., 2008; Klinge, et al., 2010; Krahn, et al., 2009a; Mahjneh, et al., 1996; Nguyen, et al., 2005; Tagawa, et al., 2003; Takahashi, et al., 2003)). Accordingly, most of the UMD -DYSF ent ries corres pond to "private" or ra re DYSF disease-causing mutations. In th e 401 reported index patients, 266 disease-causing variants were identified along the DYSF coding sequence. Within the 
index cases population, 379 het erozygous variants and 178 homozygous variants were identified and constitute a set of 735 alleles.

\section{Founder mutations and recurrent mutations}

Among DYSF $\mathrm{d}$ isease-causing mutations, se ven $\mathrm{d}$ ifferent fo under mutations have $\mathrm{b}$ een su ggested o $\mathrm{r}$ demonstrated i n pat ients of $\mathrm{v}$ arious geographic/ethnic origins ( Argov, et al ., 2000; C agliani, et al ., 2003; Leshinsky-Silver, et al., 2007; S antos, et al., 2010; Vernengo, et al., 2011; Vilchez, et a 1., 2005; Weiler, et al., 1999) (Table 2). In addition, interrogation of the database shows that 51 mutations have been recurrently identified in at least th ree non-related in dex $\mathrm{p}$ atients (see $\mathrm{u}$ pdated list $\mathrm{o} \mathrm{n}$ th e UMD -DYSF website). T hese recu rrent mutations are di stributed al ong the coding s equence and canonic splice sites without any apparen $t$ mutational « hotspot » (Figure 1).

Table 2. List of DYSF founder mutations

\begin{tabular}{|c|c|c|c|}
\hline $\begin{array}{l}\text { Mutation nomenclature on cDNA } \\
\text { (RNA, protein) }\end{array}$ & $\begin{array}{l}\text { Geographic/ethnic } \\
\text { origin of the } \\
\text { population }\end{array}$ & $\begin{array}{l}\text { Evaluated } \\
\text { carrier } \\
\text { frequency } \mathrm{Re} \\
\end{array}$ & ference \\
\hline $\begin{array}{l}\text { c.1180_1180+7delAGTGCGTG } \\
\text { (r.1054_1284del, } \\
\text { p.Glu353_Leu429del) }\end{array}$ & Portuguese & Unknown & Vernengo et al., 2011 \\
\hline $\begin{array}{l}\text { c. } 2372 \mathrm{C}>\mathrm{G} \\
\text { (p.Pro791Arg) }\end{array}$ & Native canadian & Unknown & Weiler et al., 1999 \\
\hline $\begin{array}{l}\text { c.2779delG } \\
\text { (p.Ala927LeufsX21) }\end{array}$ & Caucasian jewish & $4 \%$ & Leshinsky-Silver et al., 2007 \\
\hline $\begin{array}{l}\text { c. } 2875 \mathrm{C}>\mathrm{T} \\
\text { (p.Arg959Trp) }\end{array}$ & Italian & Unknown & Cagliani et al., 2003 \\
\hline $\begin{array}{l}\text { c.4872_4876delinsCCCC } \\
\text { (p.Glu1624AspfsX10) }\end{array}$ & Libyan jewish & $10 \%$ & Argov et al., 2000 \\
\hline c.5492G >A (exon skipping) & Portuguese & Unknown & Santos et al., 2010 \\
\hline $\begin{array}{l}\text { c. } 5713 \mathrm{C}>\mathrm{T} \\
(\mathrm{p} . \operatorname{Arg} 1905 \mathrm{X})\end{array}$ & $\begin{array}{l}\text { Spanish (region of } \\
\text { Sueca) }\end{array}$ & $2 \%$ & Vilchez et al., 2005 \\
\hline
\end{tabular}

Mutations are described using the official nomenclature of the Human Genome Variation Society, and relating to the human DYSF cDNA sequence of reference (isoform 8, GenBank \#NM_003494.2). 

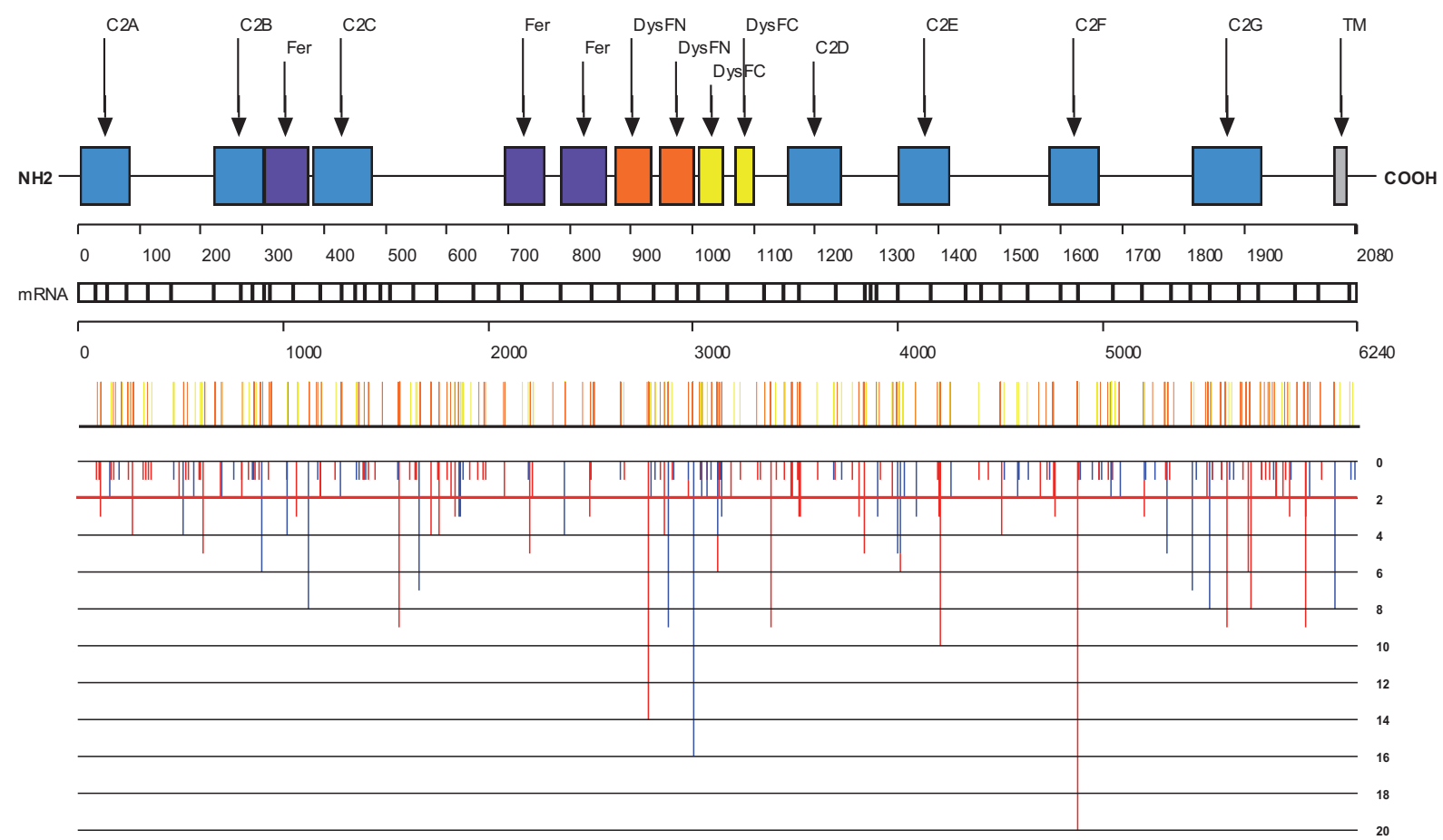

Figure 1. Distribution of exonic disease-causing mutations reported in the dysferlin sequence. Above a scale at the amino acid level, the colored boxes represent the various structural or functional domains annotated for the protein. Above a scale at the nucleotide le vel, the various white box es represent the exons of the gene. The middle panel dis plays the dis tribution of all exonic mutations identified in $\mathrm{p}$ atients first dia gnosed with LGMD2B (yellow vertical line s) or Mi yoshi m yopathy (ora nge vertical line s). The bottom pa nel dis plays the num ber of the $\mathrm{v}$ arious e xonic m utational e ntries found in the in dex $\mathrm{c}$ ases population a nd $\mathrm{c}$ lassified as missense a nd in- frame ins ertion or de letion $\mathrm{m}$ utations ( blue $\mathrm{v}$ ertical line s) or nons ense a nd frameshifting mutations (red vertical lines). Mutations below the red horizontal line represent recurrent mutations identified in at least three non-related index patients.

\section{Type of mutational events}

Among the 266 different reported mutational events, the following type of mutations were identified: 175 single base su bstitutions $(65.8 \%)$ ), 54 del etions $(20.3 \%), 26$ du plications $(9.8 \%), 6 \mathrm{i}$ nsertions $(2.3 \%)$ an $\mathrm{d} 5$ insertion/deletions (1.9\%). Am ong t he to tal d eletion an $\mathrm{d}$ in sertion e vents, $51.8 \%$ o f deletions a nd $68.7 \%$ o f insertions occurred within a repeated sequence. A total of $220(82.7 \%)$ distinct mutations affect exonic sequences and the re maining $46(17.3 \%)$ mutations involve change of in tronic nucleotides. Altogether, a mong all d iseasecausing mutations i n U MD-DYSF, e xonic mutations s egregate into missense mutations $(33.1 \%), \mathrm{n}$ onsense mutations $(18.0 \%)$, f rameshifting mutations $(27.8 \%)$ a nd i n-frame ex onic i nsertions or del etions $(3.8 \%)$ (Table 3A). The partition of the different mutation types found within the UMD-DYSF allele set is summarized in Table 3B. M oreover, U MD-DYSF $r$ eports si $x 1$ arge $r$ earrangements fo und i $n$ e ight $i$ ndex $p$ atients i nvolving deletion or du plication of on e or s everal e xons ( $\mathrm{T}$ able 4). B ecause s uch larg e mutational e vents are $\mathrm{n}$ ot systematically search ed for in genetic tes ting, this figure is ex pected to be an underestimate of the real larg e rearrangements frequency (Krahn, et al., 2009b). 
Table 3. Types of disease-causing mutations recorded in UMD-DYSF

\begin{tabular}{|c|c|c|c|c|}
\hline Type of mutations & $\begin{array}{l}\text { A. Number } \\
\text { of different } \\
\text { mutations }\end{array}$ & $\begin{array}{l}\text { B. Number of } \\
\text { alleles from } \\
\text { index patients* }\end{array}$ & $\begin{array}{l}\text { C. Number of } \\
\text { homozygous } \\
\text { alleles from } \\
\text { LGMD2B index } \\
\text { patients* }\end{array}$ & $\begin{array}{l}\text { D. Number of } \\
\text { homozygous } \\
\text { alleles from } \\
\text { Miyoshi index } \\
\text { patients* }\end{array}$ \\
\hline Exonic point mutations & $136(51.1 \%)$ & $365(49.7 \%)$ & $70(46.1 \%)$ & $62(40.3 \%)$ \\
\hline Missenses & $88(33.1 \%)$ & $236(32.1 \%)$ & $56(36.8 \%)$ & $30(19.5 \%)$ \\
\hline Nonsenses & $48(18.0 \%)$ & $129(17.6 \%)$ & $14(9.2 \%)$ & $32(20.8 \%)$ \\
\hline $\begin{array}{l}\text { Exonic deletions and } \\
\text { insertions }\end{array}$ & $84(31.6 \%)$ & $261(35.5 \%)$ & $54(35.5 \%)$ & $74(48.1 \%)$ \\
\hline Deletions & $49(18.4 \%)$ & $149(20.3 \%)$ & $28(18.4 \%)$ & $42(27.3 \%)$ \\
\hline Out of frame deletions & $45(16.9 \%)$ & $139(18.9 \%)$ & $24(15.8 \%)$ & $40(26.0 \%)$ \\
\hline In frame deletions & $4(1.5 \%)$ & $10(1.4 \%)$ & $4(2.6 \%)$ & $2(1.3 \%)$ \\
\hline Insertions & $30(11.3 \%)$ & $74(10.1 \%)$ & $14(9.2 \%)$ & $16(10.4 \%)$ \\
\hline Out of frame insertions & $27(10.2 \%)$ & $71(9.7 \%)$ & $14(9.2 \%)$ & $16(10.4 \%)$ \\
\hline In frame insertions & $3(1.1 \%)$ & $3(0.4 \%)$ & $0(0.0 \%)$ & $0(0.0 \%)$ \\
\hline Indels & $5(1.9 \%)$ & $38(5.2 \%)$ & $12(7.9 \%)$ & $16(10.4 \%)$ \\
\hline Out of frame indels & $2(0.8 \%)$ & $33(4.5 \%)$ & $6(6.6 \%)$ & $0(0 \%)$ \\
\hline In frame indels & $3(1.1 \%)$ & $5(0.7 \%)$ & $2(1.3 \%)$ & $16(10.4 \%)$ \\
\hline Intronic mutations & $46(17.3 \%)$ & $109(14.8 \%)$ & $28(18.4 \%)$ & $18(11.7 \%)$ \\
\hline TOTAL & $266(100 \%)$ & $735(100 \%)$ & $152(100 \%)$ & $154(100 \%)$ \\
\hline
\end{tabular}

All percentages are cal culated with respect to the value in the TOTAL line. * For each patient, heterozygous disease-causing mutations are counted once and homozygous disease-causing mutations are counted twice.

Table 4. List of large rearrangements identified in the DYSF gene

\begin{tabular}{lll}
\hline Mutation nomenclature & Duplicated or deleted exons & Number of occurrence in probands \\
\hline c. $89-643 \_4411-2493$ del & 2 to 40 & 1 \\
\hline c.343-? $457+?$ del 5 & & 1 \\
\hline c. $2512-?+3174+$ ?del & 25 to 29 & 3 \\
\hline c.3904-? $4333+$ ?dup & 37 to 39 & 1 \\
\hline c.5768-? 5946+?del 52 & & 1 \\
\hline c.6205-?*+?del 55 & & 1
\end{tabular}

Large deletions can be displayed using the "Deletion Map" function on the UMD-DYSF website. Mutations are described using the o fficial $\mathrm{n}$ omenclature of the Hu man Genome V ariation S ociety, an d rel ating to the hu man DYSF c DNA s equence of reference (isoform 8, GenBank \#NM_003494.2).

\section{Exonic variants}

The 220 exonic mutations are distributed along the entire coding sequence, affecting regions of the protein both within or outside of predicted functional domains, and without any defined mutational hotspot (Figure 1). A total of 122 exonic mutations are predicted to disrupt the open reading frame and/or to lead to a premature stop codon. These mutations can be class ified in to insertions or deletions events ( 74 frameshifting mutations) and nonsense mutations (48 mutations) (T able 3A) an d are found e venly di stributed al ong the codi ng s equence (Fi gure 1). Overall, the events that presumably lead to the translation of a tr uncated and unstable dysferlin protein represent $50.6 \%$ of the proband allele population (Table 3B). We examined the distribution of missense and in-frame exonic 
insertion or del etion mutations a nd co mpared $t$ heir proport ion ei ther within or out side ann otated do mains (Figure 1). We s how that mutations recorded in U MD-DYSF aff ect 3.3\% of al 1 am ino aci ds res iding ou tside annotated do mains a nd $5.0 \%$ of al 1 a mino aci ds res iding within do mains. In part icular, we conf irm $t$ he susceptibility of the repeated DysF domain to mutations (Patel, et al., 2 008) as the UMD-DYSF mutations affect $7.9 \%$ of the a mino aci ds within $t$ his do main. $T$ he "Structure" fu nction s ummarizes the dis tribution of s mall rearrangements in structural domains and in possible calcium binding residues of the dysferlin protein. Within the group of proband alleles, $453(81.3 \%)$ correspond to DYSF variants mutated within regions encoding a predicted structural or $\mathrm{f}$ unctional do main. O verall, $\mathrm{C} 2$ do mains are $\mathrm{t}$ he most frequently a ffected ( $266 \mathrm{~m}$ utational e ntries), followed b y D ysF a nd ferlin dom ains (126 an d $60 \mathrm{~m}$ utational en tries, res pectively) whereas on e si ngle index patient was identified with a deleterious mutation (12 bp insertion/deletion) in the region coding for the carboxyterminal $t$ ransmembrane do main ( $G$ uglieri, et al ., 2008). I nterestingly, mutations i n pr edicted cal cium bi nding residues of $\mathrm{C} 2$ domains were reported for only three patients, within $\mathrm{C} 2 \mathrm{~B}, \mathrm{C} 2 \mathrm{C}$ and $\mathrm{C} 2 \mathrm{~F}$ domains (De Luna, et al., 2007; Nguyen, et al., 2005; Walter, et al., 2003).

\section{Splice variants}

Among the 266 different mutational events reported in UMD-DYSF, 46 splice variants consist of both intronic or exonic mutations associated with a predicted or ex perimentally described abnormal splicing of the DYSF gene (Table 5). Intronic variants i nclude 31 mutations di rectly a ffecting 5 ' splice don or-sites, $14 \mathrm{~m}$ utations affecting 3 ' splice acceptor-sites and one deleterious mutation within a branchpoint signal. In addition, two exonic mutations have been shown to produ ce aberran tly spliced trans cripts b y ei ther abolis hing the ca nonical don or splice site (c.5429G $>$ A) (Santos, et al., 2010 ) or by creating a n ovel ectopic acceptor splice site (c.1555G $>$ A) (De L una, et al., 200 7). A ltogether, s plice v ariants con stitute $14.8 \%$ of the al lele popu lation in U MD-DYSF index pat ients (Table 3B). U sing dedi cated functions i ncluded in U MD and H SF, a pat hogenic e ffect on the s plice don or or acceptor sites, or in the branchpoint (c.3443-33A>G), was correctly predicted in all cases, exception made for one mutation, c.5525+3A $>$ G. This mutation was shown to pro mote ex on 49 s kipping (De Luna, et a 1., 2007). H SF analysis predicts an effect on the splice don or site, but below the threshold of pat hogenicity. However, possible effects on exonic splicing enhancer and silencer sites are also predicted, and may cause the experimentally proven exon 49 skipping in this case.

\section{Mutation status}

Altogether, 280 patients carry at least one homozygous mutation. Among them, two patients carry two or three homozygous mutations (F 1-47-1-2 and F 1-18-1-2) an d hree pat ients carr y on e homozygous mutation and on e heterozygous mutation (U K2-29-1-0, U K2-47-1-0 and U K2-49-1-0). A total of 176 pat ients carr y at 1 east $t$ wo compound heterozygous mutations, including two patients carrying three heterozygous mutations (F1-65-1-2 and UK2-35-1-0). The identification of more than two distinct possibly disease-causing mutations in a patient may be related t o t he ex istence of hypomorphic sequence $\mathrm{v}$ ariants, or co mplex a lleles. F or 102 pat ients, on ly on e heterozygous disease-causing $\mathrm{m}$ utation $\mathrm{w}$ as iden tified. Am ong these are two $\mathrm{s}$ ymptomatic dysferlin $\mathrm{m}$ utation carriers described by Illa and colleagues (Illa, et al., 2007). Overall, both disease-causing alleles were identified in 323 index patients $(80.5 \%)$, whereas on ly on e di sease-causing al lele was identified in the ot her 78 i ndex cas es (19.5\%), th us underlining incomplete se nsitivity of the cu rrently u sed mutation detection tec hniques. Ho wever, these figures do $n$ ot reflect the overall detection rate of dysferlin mutation screening procedures since in patients with a cli nical d iagnosis of dysferlinopathy, it is e stimated th at for ap proximately $10 \%$ of them, mutational analyses did not confirm them as carriers of any disease-causing mutation in the dysferlin gene and these patients are th us $n$ ot reco rded in UMD-DYSF (the in clusion criter ia b eing the id entification of at least $o$ ne d eleterious mutation). 
Table 5. List of reported splice mutations within the DYSF gene

\begin{tabular}{|c|c|c|c|}
\hline Localisation & Mutation nomenclature & Effect at the RNA & Original description \\
\hline IVS3 & c. $236+1 \mathrm{G}>\mathrm{T}$ & r.143_236del (E3S, FS) & Liewluck et al. 2009 \\
\hline IVS5 & c. $457+1$ insG & r.spl? & Nguyen et al. 2005 \\
\hline IVS5 & c. $457+2 \mathrm{~T}>\mathrm{G}$ & r.343_457del (E5S, FS) & Cagliani et al. 2005 \\
\hline IVS6 & c. $663+1 \mathrm{G}>\mathrm{C}$ & r.spl? & Saito et al. 2002 \\
\hline IVS6 & c.664-9_667del13 & r.spl? & Klinge et al. 2010 \\
\hline IVS8 & c. $855+1 \mathrm{delG}$ & r.spl? & Nguyen et al. 2005 \\
\hline IVS10 & c. $937+1 \mathrm{G}>\mathrm{A}$ & r.spl? & Saito et al. 2002 \\
\hline IVS11 & c. $1053+5 \mathrm{G}>\mathrm{A}$ & r.spl? & Klinge et al. 2008 \\
\hline IVS12 & c. $1180+2 \mathrm{~T}>\mathrm{C}$ & r.spl? & Cuglieri et al. 2008 \\
\hline IVS12 & c. $1181-2 \mathrm{~A}>\mathrm{C}$ & r.1181_1212del (FS) & Cagliani et al. 2005 \\
\hline IVS13 & c. $1284+2 \mathrm{~T}>\mathrm{C}$ & r.spl? & Tagawa et al. 2003 \\
\hline IVS13 & c. $1285-2 A>G$ & r.spl? & Spuler et al. 2008 \\
\hline IVS14 & c. $1353+1 \mathrm{G}>\mathrm{A}$ & [r.1353+1_1354-1ins; r.1353+1g>a] (I14R, FS) & de Luna et al. 2007 \\
\hline IVS14 & c. $1354-1 \mathrm{G}>\mathrm{A}$ & r.spl? & Klinge et al. 2010 \\
\hline IVS16 & c. $1480+1 \mathrm{delG}$ & r.1398_1480del (E16S, FS) & Therrien et al. 2006 \\
\hline IVS16 & c. $1481-1 \mathrm{G}>\mathrm{A}$ & r.spl? & Rosales et al. 2010 \\
\hline Exon17 & c. $1555 \mathrm{G}>\mathrm{A}$ & r.1523_1556del (FS) & de Luna et al. 2007 \\
\hline IVS22 & c. $2163-1 \mathrm{G}>\mathrm{T}$ & r.spl? & Klinge et al. 2010 \\
\hline IVS24 & c. $2511+1 \mathrm{G}>\mathrm{A}$ & r.spl? & Nguyen et al. 2005 \\
\hline IVS25 & c. $2643+1 \mathrm{G}>\mathrm{A}$ & r.spl? & Matsuda et al. 2001 \\
\hline IVS25 & c. $2643+2 \mathrm{~T}>\mathrm{C}$ & r.spl? & Klinge et al. 2010 \\
\hline IVS25 & c. $2643+2 \mathrm{~T}>\mathrm{G}$ & r.2512_2643del (E25S, IF) & Therrien et al. 2006 \\
\hline IVS25 & c. $2644-2 A>G$ & r.spl? & Matsuda et al. 2001 \\
\hline IVS26 & c. $2810+1 \mathrm{G}>\mathrm{A}$ & r.spl? & Nguyen et al. 2005 \\
\hline IVS26 & c. $2810+1 \mathrm{G}>\mathrm{C}$ & r.spl? & Cuglieri et al. 2008 \\
\hline IVS28 & c. $3031+2 \mathrm{~T}>\mathrm{C}$ & r.spl? & Nguyen et al. 2005 \\
\hline IVS30 & c. $3348+1$ delGTAT & r.spl? & Nguyen et al. 2005 \\
\hline IVS30 & c. $3349-2 \mathrm{~A}>\mathrm{G}$ & r.spl? & Klinge et al. 2010 \\
\hline IVS31 & c. $3443-33 \mathrm{~A}>\mathrm{G}$ & r.3443_3520del (E32S, IF) & Sinnreich et al. 2006 \\
\hline IVS33 & c. $3702+1 \mathrm{G}>\mathrm{A}$ & r.spl? & Nguyen et al. 2005 \\
\hline IVS33 & c. $3703-1 \mathrm{G}>\mathrm{A}$ & r.spl? & Nguyen et al. 2005 \\
\hline IVS34 & c. $3843+1 \mathrm{G}>\mathrm{A}$ & r.spl? & Nguyen et al. 2005 \\
\hline IVS34 & c. $3843+2 \mathrm{~T}>\mathrm{A}$ & r.spl? & Rosales et al. 2010 \\
\hline IVS37 & c. $4005+1 \mathrm{G}>\mathrm{A}$ & r.spl? & Nguyen et al. 2005 \\
\hline IVS38 & c. $4167+1 \mathrm{G}>\mathrm{C}$ & r.spl? & Nguyen et al. 2005 \\
\hline
\end{tabular}




\begin{tabular}{llll}
\hline Localisation & Mutation nomenclature & Effect at the RNA & Original description \\
\hline IVS40 & c.4411-5C $>\mathrm{G}$ & r.spl? & Klinge et al. 2008 \\
\hline IVS45 & c.5057+4_delCGT & r.?_5057del (FS) & Cagliani et al. 2003 \\
\hline IVS45 & c.5057+5G $>$ A & r.spl & McNally et al. 2000 \\
\hline IVS45 & c.5057+4_5057+5ins23 & r.spl? & Anderson et al. 2000 \\
\hline IVS46 & c.5200+1G $>$ A & r.spl? & Cagliani et al. 2005 \\
\hline IVS47 & c.5341-1G $>$ A & r.spl? & Klinge et al. 2010 \\
\hline Exon48 & c.5429G $>$ A & r.5341_5429del * (E48S, FS) & Santos et al. 2010 \\
\hline IVS48 & c.5430-2A $>\mathrm{G}$ & r.spl? & Kesari et al. 2008 \\
\hline IVS49 & c.5525+3A $>\mathrm{G}$ & r.5430_5525del (E49S, IF) & De Luna et al. 2007 \\
\hline IVS49 & c.5526-1G $>$ A & r.spl? & Rosales et al. 2010 \\
\hline IVS50 & c.5668-7G $>$ A & [r. 5668-5_5668-1ins;r.5668-7g $>$ a ] (FS) & Cagliani et al. 2005 \\
\hline IVS51 & c.5767+1G $>$ A & r.spl? & Nguyen et al. 2005 \\
\hline IVS52 & c.5946+1G $>$ A & r.spl? & Liu et al. 1998 \\
\hline
\end{tabular}

Mutations affect canonical intronic splice signals (5' and 3'splice sites, branchpoints) or exonic nucleotides. Effect on RNA splicing was either predicted (r.spl?) or experimentally described. Disruption of canonical splice signals or creation of novel splice signals $\mathrm{c}$ an promote ex on s kipping (ES), intron r etention (IR), or ot her s equence ins ertion/deletion in $t$ he $\mathrm{m}$ RNA. Mutations are predicted to either maintain the reading frame (IF) or introduce a frameshift (FS) leading to the translation of a truncated product and possibly to nonsense-mediated mRNA decay. * Predominant transcript. Mutations are described using the of ficial no menclature of the Human Genome Variation Soc iety, and relating to the hum an DYSF c DNA s equence of reference (isoform 8, GenBank \#NM_003494.2).

\section{Comparison of mutational profiles of the LGMD2B and Miyoshi myopathy phenotypes}

Dysferlinopathies are ch aracterized by the two main clinical phenotypes, LGMD2B and Miy oshi myopathy, and additional clinical variants, thus presenting a b road range of symptoms and onset. In all cases th e genotypephenotype rel ationship has al ways re mained di fficult to d efine. In U MD-DYSF, $88 \%$ of pat ients pres ent with either a L GMD2B or Miyoshi myopathy phenotype, as described in the original publications. We have compared the distribution of the mutations along the DYSF gene (Figure 1) and the type of mutations between the two main clinical groups (Table $3 \mathrm{C}$ and $\mathrm{D}$, with patients with one homozygous mutation) and no significant difference was observed between them $\left(\mathrm{Chi}^{2}\right.$ test, $\left.\mathrm{p}>0.01\right)$. Therefore, available mutational data do not point out any genotypephenotype co rrelation for dysferlin mutations with re gard to the t wo main cl inical p resentations, LGMD2B or Miyoshi myopathy. It can be speculated that the observed clinical heterogeneity in dysferlinopathies may rather be related to the implication of genetic or environmental modifiers.

\section{DATABASE UPDATE}

The UMD- DYSF v 1.0 databas e an $\mathrm{d}$ s ubsequent $\mathrm{u}$ pdated $\mathrm{v}$ ersions are av ailable at www .umd.be/DYSF/. Curation of the UMD-DYSF $d$ atabase $b$ y a d edicated cu rator will al low co ntinuous updating. $\mathrm{Cl}$ inicians an $\mathrm{d}$ researchers are en couraged to submit unpublished variants by contacting the curator of the database. Notification of omissions and errors in the current version, as well as specific phenotypic data, would be gratefully received by the curator. The software package is available on a collaborative basis and will be expanded as the database grows, with the implementation of new specific functions according to the requirements of its users. In referring to UMDDYSF, we kindly ask all users of the database to cite this article. 


\section{ACKNOWLEDGMENTS}

We sin cerely th ank Kate B ushby, B rigitta von Rekowski an d Han ns Lochmüller for h elpful ad vice o $n$ the UMD-DYSF website, Andrew Phillips for his help with the HGMD s tatistics, and B runo Eymard, Jean Pouget, Shahram Attarian and Emmanuelle Campana-Salort for helpful discussions.

\section{REFERENCES}

Aartsma-Rus A, Singh KH, Fokkema IF, Ginjaar IB, van Ommen GJ, den Dunnen JT, van der Maarel SM. 2010. Therapeutic exon skipping for dysferlinopathies? Eur J Hum Genet 18(8):889-94.

Aoki M, Liu J, Ric hard I, Ba shir R, Britton S, Ke ers SM, Oe ltjen J, Brown HE, Ma rchand S, Bou rg N, Be ley C, Mc KennaYasek D, Arahata K, Bohlega S, Cupler E, Illa I, Majneh I, Barohn RJ, Urtizberea JA, Fardeau M, Amato A, Angelini C, Bushby K, Beckmann JS, Brown RH, Jr. 2001. Genomic organization of the dysferlin gene and novel mutations in Miyoshi myopathy. Neurology 57(2):271-8.

Argov Z, Sadeh M, Mazor K, Soffer D, Kahana E, Eisenberg I, Mitrani-Rosenbaum S, Richard I, Beckmann J, Keers S, Bashir R, Bushby K, Rosenmann H. 2000. Muscular dy strophy due to dysferlin de ficiency in L ibyan Jews. Clinical and genetic features. Brain 123 ( Pt 6):1229-37.

Bansal D, Miyake K, Vogel SS, Groh S, Chen CC, Williamson R, McNeil PL, Campbell KP. 2003. Defective membrane repair in dysferlin-deficient muscular dystrophy. Nature 423(6936):168-72.

Bashir R, Britton S, Strachan T, Keers S, Vafiadaki E, Lako M, Richard I, Marchand S, Bourg N, Argov Z, Sadeh M, Mahjneh I, Marconi G, Passos-Bueno MR, Moreira Ede S, Zatz M, Beckmann JS, Bushby K. 1998. A gene related to Caenorhabditis elegans spermatogenesis factor fer-1 is mutated in limb-girdle muscular dystrophy type 2B. Nat Genet 20(1):37-42.

Beroud C, Collod-Beroud G, Boileau C, Soussi T, Junien C. 2000. UMD (Universal mutation database): a generic software to build and analyze locus-specific databases. Hum Mutat 15(1):86-94.

Beroud C, Hamroun D, Collod-Beroud G, Boileau C, Soussi T, Claustres M. 2005. UMD (Universal Mutation Database): 2005 update. Hum Mutat 26(3):184-91.

Bushby KM. 2000. Dysferlin and muscular dystrophy. Acta Neurol Belg 100(3):142-5.

Cagliani R, Fo rtunato F, Giorda R, Ro dolico C, Bonaglia MC, Sironi M, D' Angelo MG, Prelle A, Locatelli F, T oscano A, Bresolin N, Comi GP. 2003. Molecular analysis of L GMD-2B and MM patients: identification of novel DYSF mutations and possible founder effect in the Italian population. Neuromuscul Disord 13(10):788-95.

Collod-Beroud G, Le Bourdelles S, Ades L, Ala-Kokko L, Booms P, Boxer M, Child A, Comeglio P, De Paepe A, Hyland JC, Holman K, K aitila I, L oeys B, Matyas G, Nu ytinck L, P eltonen L, Rantamaki T, Robinson P, Steinmann B, Junie n C, Beroud C, Boileau C. 2003. Update of the UMD-FBN1 mutation database and creation of an FBN1 polymorphism database. Hum Mutat 22(3):199-208.

De Luna N, Freixas A, Gallano P, Caselles L, Rojas-Garcia R, Paradas C, Nogales G, Dominguez-Perles R, Gonzalez-Quereda L, V ilchez JJ, Marquez C, Bau tista J, Guerrero A, S alazar J A, P ou A, Il la I, Gallardo E. 2007. Dysferlin exp ression in monocytes: a source of mRNA for mutation analysis. Neuromuscul Disord 17(1):69-76.

den Dunnen JT, Antonarakis SE. 2000. Mutation nomenclature extensions and suggestions to de scribe complex mutations: a discussion. Hum Mutat 15(1):7-12.

Desmet FO, H amroun D, Lalande M, C ollod-Beroud G, C laustres M, B eroud C. 2009. H uman Splic ing Finder: an online bioinformatics tool to predict splicing signals. Nucleic Acids Res 37(9):e67.

Dreszer TR, Karolchik D, Zweig AS, Hinrichs AS, Raney BJ, Kuhn RM, Meyer LR, Wong M, Sloa n CA, Rosenbloom KR, Roe G, Rhead B, Pohl A, Malladi VS, Li CH, Learned K, Kirkup V, Hsu F, Harte RA, Guruvadoo L, Goldman M, Giardine BM, Fujita PA, Diekhans M, Cline MS, Cla wson H, Ba rber GP, Haussler D, Ja mes Kent W. 201 1. The UCSC Genome Browser database: extensions and updates 2011. Nucleic Acids Res.

Finn RD, M istry J, T ate J, Cogg ill P, He ger A, P ollington JE, Gavin OL, Gunasekaran P, Ce ric G, Forslun d K, H olm L, Sonnhammer E L, Eddy SR, Ba teman A. 201 0. T he P fam prot ein families da tabase. Nuc leic Acids Re s 38(Da tabase issue):D211-22. 
Foxton R M, Laval SH, B ushby K M. 20 04. C haracterisation of the dy sferlin s keletal muscle promoter. Eur J H um Genet $12(2): 127-31$.

Frederic MY, Hamroun D, Faivre L, Boileau C, Jondeau G, Claustres M, B eroud C, Collod-Beroud G. 2008. A new locusspecific database (LSDB) for mutations in the TGFBR2 gene: UMD-TGFBR2. Hum Mutat 29(1):33-8.

Frederic MY, Lalande M, B oileau C, Hamroun D, Claustres M, B eroud C, Collod-Beroud G. 2009. U MD-predictor, a new prediction tool for nucleotide substitution pathogenicity -- application to four genes: FBN1, FBN2, TGFBR1, and TGFBR2. Hum Mutat 30(6):952-9.

Guglieri M, Magri F, D'Angelo MG, Prelle A, Morandi L, Rodolico C, Cagliani R, Mora M, Fortunato F, Bordoni A, Del Bo R, Ghezzi S, Pagliarani S, L ucchiari S, S alani S, Z ecca C, L amperti C, Ron chi D, A guennouz M, Ciscato P, Di Bl asi C, Ruggieri A, Moroni I, Turconi A, Toscano A, Moggio M, B resolin N, Comi GP. 2008. Clinical, molecular, a nd protein correlations i $\mathrm{n}$ a la rge $\mathrm{s}$ ample of $\mathrm{g}$ enetically dia gnosed I talian $\lim \mathrm{b} g$ irdle $\mathrm{m}$ uscular $\mathrm{d}$ ystrophy pa tients. H um Muta $\mathrm{t}$ 29(2):258-66.

Ho M, Gallardo E, McKenna-Yasek D, De Luna N, Illa I, Brown Jr RH. 2002. A novel, blood-based diagnostic assay for limb girdle muscular dystrophy 2B and Miyoshi myopathy. Ann Neurol 51(1):129-33.

Illa I, D e L una N, D ominguez-Perles R, R ojas-Garcia R, P aradas C, P almer J, Ma rquez C, G allano P, Gallardo E. 2007. Symptomatic dysferlin gene mutation carriers: characterization of two cases. Neurology 68(16):1284-9.

Illa I, Serrano-Munuera C, Gallardo E, Lasa A, Rojas-Garcia R, Palmer J, Gallano P, Baiget M, Matsuda C, Brown RH. 2001. Distal a nterior c ompartment myopathy: a dy sferlin mutation c ausing a new muscular dy strophy phenotype. A nn Neurol 49(1):130-4.

Khadilkar SV , Si ngh R K, A garwal P, K rahn M, L evy N. 200 8. T wenty-two year follow-up of a $\mathrm{n}$ I ndian f amily with dysferlinopathy-clinical, immunocytochemical, western blotting and genetic features. Neurol India 56(3):388-90.

Klinge L, Aboumousa A, Eagle M, Hudson J, Sarkozy A, Vita G, Charlton R, Roberts M, Straub V, Barresi R, Lochmuller H, Bushby K . 2010 . N ew a spects on pa tients a ffected b y d ysferlin de ficient $\mathrm{m}$ uscular $\mathrm{d}$ ystrophy. J $\mathrm{N}$ eurol $\mathrm{N}$ eurosurg Psychiatry 81(9):946-53.

Klinge L, Dean AF, Kress W, Dixon P, Charlton R, Muller JS, Anderson LV, Straub V, Barresi R, Lochmuller H, Bushby K. 2008. Late onset in dysferlinopathy widens the clinical spectrum. Neuromuscul Disord 18(4):288-90.

Krahn M, B eroud C, Labelle V, Nguyen K, Bernard R, Bassez G, Figarella-Branger D, Fernandez C, Bouvenot J, Richard I, Ollagnon-Roman E, Be vilacqua J A, Salvo E, A ttarian S, Cha pon F, Pellissier JF, Pouget J, Hammouda el H, La foret P, Urtizberea J A, E ymard B, L eturcq F, L evy N. 2009a. A nalysis of the D YSF m utational s pectrum in a la rge cohort of patients. Hum Mutat 30(2):E345-75.

Krahn M, B orges A, Navarro C, Sc huit R, Stojkovic T, Torrente Y, W ein N, Pecheux C, Levy N. 2009b. Identification of different genomic deletions and one duplication in the dysferlin gene using multiplex ligation-dependent probe amplification and genomic quantitative PCR. Genet Test Mol Biomarkers 13(4):439-42.

Krahn M, W ein N, B artoli M, Lostal W, C ourrier S, B ourg-Alibert N, N guyen K, Vial C, Str eichenberger N, L abelle V, DePetris D, P echeux C, Leturcq F, C au P, Richard I, Levy N. 2010. A na turally oc curring human minidysferlin protein repairs sarcolemmal lesions in a mouse model of dysferlinopathy. Sci Transl Med 2(50):50ra69.

Laval SH, B ushby K M. 2 004. Limb-girdle muscular d ystrophies--from g enetics to m olecular pa thology. N europathol A ppl Neurobiol 30(2):91-105.

Lennon NJ, Kho A, Bacskai BJ, Perlmutter SL, Hyman BT, Brown RH, Jr. 2003. Dysferlin interacts with annexins A1 and A2 and mediates sarcolemmal wound-healing. J Biol Chem 278(50):50466-73.

Leshinsky-Silver E, A rgov Z, R ozenboim L, C ohen S, T zofi Z, C ohen Y, W irguin Y, D abby R, L ev D, Sa deh M . 2007. Dysferlinopathy in the Jews of the Caucasus: a frequent mutation in the dysferlin gene. Neuromuscul Disord 17(11-12):9504.

Letunic I, D oerks T, B ork P . 2009. SMA RT 6: $\mathrm{r}$ ecent updates a nd ne w de velopments. N ucleic Acids R es 37( Database issue):D229-32.

Levy N, Wein N , B arthelemy F, M ouly V, G arcia L, K rahn M, B artoli M . 2 010. T herapeutic e xon ' switching' for dysferlinopathies? Eur J Hum Genet 18(9):969-70; author reply 971. 
Liu J, Aoki M, Illa I, Wu C, Fardeau M, Angelini C, Serrano C, Urtizberea JA, Hentati F, Hamida MB, Bohlega S, Culper EJ, Amato AA, Bossie K, Oeltjen J, Bejaoui K, McKenna-Yasek D, Hosler BA, Schurr E, Arahata K, de Jong PJ, Brown RH, Jr. 1998. Dysferlin, a novel skeletal muscle gene, is mutated in Miyoshi myopathy and limb girdle muscular dystrophy. Nat Genet 20(1):31-6.

Mahjneh I, Bushby K, Pizzi A, Bashir R, Marconi G. 1996. Limb-girdle muscular dystrophy: a follow-up study of 79 patients. Acta Neurol Scand 94(3):177-89.

Nguyen K, Bassez G, Bernard R, Krahn M, Labelle V, Figarella-Branger D, Pouget J, Hammouda el H, Beroud C, Urtizberea A, E ymard B , Leturcq F, L evy N . 2005. D ysferlin mutations in L GMD2B, Miy oshi myopathy, a nd a typical dysferlinopathies. Hum Mutat 26(2):165.

Nguyen K, Bassez G, Krahn M, Bernard R, Laforet P, Labelle V, Urtizberea JA, Figarella-Branger D, R omero N, A ttarian S, Leturcq F, P ouget J, L evy N, Eymard B . 2007. Phenotypic s tudy in 40 pa tients w ith dy sferlin g ene mutations: hig h frequency of atypical phenotypes. Arch Neurol 64(8):1176-82.

Okahashi S, Ogawa G, Suzuki M, Ogata K, Nishino I, Kawai M. 2008. Asymptomatic sporadic dysferlinopathy presenting with elevation of serum creatine kinase. Typical distribution of muscle involvement shown by MRI but not by CT. Intern Med 47(4):305-7.

Paradas C, Gonzalez-Quereda L, De Luna N, Gallardo E, Garcia-Consuegra I, Gomez H, Cabello A, Illa I, Gallano P. 2009. A new phenotype of dysferlinopathy with congenital onset. Neuromuscul Disord 19(1):21-5.

Patel P, Harris R, Geddes SM, Strehle EM, Watson JD, Bashir R, Bushby K, Driscoll PC, Keep NH. 2008. Solution structure of the inner DysF domain of myoferlin and implications for limb girdle muscular dystrophy type 2b. J Mol Biol 379(5):981-90.

Pramono ZA, L ai P S, T an C L, Takeda S, Y ee W C. 2006 . I dentification a nd c haracterization of a nov el h uman dy sferlin transcript: dysferlin_v1. Hum Genet 120(3):410-9.

Pramono Z A, T an CL, S eah IA, S ee JS, Kam S Y, L ai P S, Yee W C. 2 009. Id entification and characterisation of hu man dysferlin transcript variants: implications for dysferlin mutational screening and isoforms. Hum Genet 125(4):413-20.

Salani S, Lucchiari S, Fortu nato F, Crimi M, Corti S, L ocatelli F, Bossolasco P, Bresolin N, Comi GP. 2004. Developmental and tissue-specific regulation of a novel dysferlin isoform. Muscle Nerve 30(3):366-74.

Santos R, Oliveira J, Vieira E, Coelho T, Carneiro AL, Evangelista T, Dias C, Fortuna A, Geraldo A, Negrao L, Guimaraes A, Bronze-da-Rocha E. 2010. Private dy sferlin e xon s kipping m utation ( c.5492G $>$ A) with a founder e ffect r eveals further alternative splicing involving exons 49-51. J Hum Genet 55(8):546-9.

Seror P, K rahn M, L aforet P, Leturcq F, Ma isonobe T. 2008. C omplete fatty degeneration of lumbar erector spinae muscles caused by a primary dysferlinopathy. Muscle Nerve 37(3):410-4.

Spuler S, Carl M, Z abojszcza J, S traub V, Bu shby K, M oore S A, B ahring S, W enzel K, V inkemeier U, Ro cken C. 2008. Dysferlin-deficient muscular dystrophy features amyloidosis. Ann Neurol 63(3):323-8.

Stenson PD, Ball EV, Howells K, Phillips AD, Mort M, Cooper DN. 2009. The Human Gene Mutation Database: providing a comprehensive central mutation database for molecular diagnostics and personalized genomics. Hum Genomics 4(2):69-72.

Tagawa K, Ogawa M, Kawabe K, Yamanaka G, Matsumura T, Goto K, Nonaka I, Nishino I, Hayashi YK. 2003. Protein and gene analyses of dysferlinopathy in a large group of Japanese muscular dystrophy patients. J Neurol Sci 211(1-2):23-8.

Takahashi T, Aoki M, Ta teyama M, K ondo E, Miz uno T, O nodera Y, Takano R, Kawai H, Kam akura K, Moc hizuki H, Shizuka-Ikeda M, Nakagawa M, Yoshida Y, Akanuma J, Hoshino K, Saito H, Nishizawa M, Kato S, Saito K, Miyachi T, Yamashita H, Kawai M, Matsumura T, Kuzuhara S, Ibi T, Sahashi K, Nakai H, Kohnosu T, Nonaka I, Arahata K, Brown RH, J r., I toyama Y . 2003 . D ysferlin mutations in J apanese Mi yoshi myopathy: r elationship to phe notype. N eurology 60(11):1799-804.

Therrien C, D odig D , K arpati G, Sinnr eich M . 2006. Mu tation im pact on dysferlin inf erred f rom da tabase a nalysis a nd computer-based structural predictions. J Neurol Sci 250(1-2):71-8.

Ueyama H, Kumamoto T, Horinouchi H, Fujimoto S, Aono H, Tsuda T. 2002. Clinical heterogeneity in dysferlinopathy. Intern Med 41(7):532-6.

Urtizberea JA, Bassez G, Leturcq F, Nguyen K, Krahn M, Levy N. 2008. Dysferlinopathies. Neurol India 56(3):289-97. 
Vernengo L, Oliveira J, Krahn M, Vie ira E, Santos R, Carrasco L, Negrao L, P anuncio A, Leturcq F, L abelle V, B ronze-daRocha E, Mesa R, Pizzarossa C, Levy N, Rodriguez MM. 2011. Novel ancestral Dysferlin splicing mutation which migrated from the Iberian peninsula to South America. Neuromuscul Disord.

Vilchez JJ, Gallano P, Gallardo E, Lasa A, Rojas-Garcia R, Freixas A, De Luna N, Calafell F, Sevilla T, Mayordomo F, Baiget M, Illa I. 2 005. Identification of a novel founder mutation in t he D YSF gene causing clinical variability in the Spa nish population. Arch Neurol 62(8):1256-9.

Walter MC, Bra un C, Vorgerd M, Poppe M, Thirion C, Schmidt C, Sc hreiber H, Knirsch UI, Br ummer D, Mulle r-Felber W, Pongratz D , M uller-Hocker J , Huebner A, L ochmuller H . 20 03. Va riable r eduction of c aveolin-3 i n patients w ith LGMD2B/MM. J Neurol 250(12):1431-8.

Wang B, Yang Z, Brisson BK, Feng H, Zhang Z, Welch E, Peltz S, Barton ER, Brown RH, Jr., Sweeney HL. 2010. Membrane blebbing a s a n ssessment of functional r escue of dy sferlin-deficient human m yotubes via nons ense suppression. J Appl Physiol.

Weiler T, Bashir R, Anderson LV, Davison K, Moss JA, Britton S, Nylen E, Keers S, Vafiadaki E, Greenberg CR, Bushby CR, Wrogemann K. 1999. Identical mutation in patients with limb girdle muscular dy strophy type 2 B or Miy oshi m yopathy suggests a role for modifier gene(s). Hum Mol Genet 8(5):871-7.

Wein N, Avril A, Bartoli M, Beley C, Chaouch S, Laforet P, Behin A, Butler-Browne G, Mouly V, Krahn M, Garcia L, Levy N. 2010. Efficient bypass of mutations in dysferlin deficient patient cells by antisense-induced exon skipping. Hum Mutat 31(2):136-42.

Wenzel K, Geier C, Qadri F, Hubner N, Schulz H, Erdmann B, Gross V, Bauer D, Dechend R, Dietz R, Osterziel KJ, Spuler S, Ozcelik C. 2007. Dysfunction of dysferlin-deficient hearts. J Mol Med 85(11):1203-14. 